\title{
Probiotics to prevent the need for, and augment the use of, antibiotics
}

\author{
Gregor Reid BSc (Hons) PhD MBA ${ }^{1,2}$
}

\begin{abstract}
G Reid. Probiotics to prevent the need for, and augment the use of, antibiotics. Can J Infect Dis Med Microbiol 2006;17(5):291-295.
\end{abstract}

\begin{abstract}
Although humans and microbes are inseparable, our knowledge and understanding of the majority of microbes that help keep us alive and well is in desperate need of further investigation. Of the organisms that influence humans before birth and inhabit various niches from birth to old age, we know little about their identity, origin, metabolic properties, attributes and mechanisms of interactions with the host and surrounding microbes. The use of probiotics ("live microorganisms which when administered in adequate amounts confer a health benefit on the host") has re-emerged as a means to restore and boost the beneficial microbes in our bodies. The timing of resurgent interest in this ancient field coincides with the need to augment or replace antibiotics whose side effects are unwelcome and whose efficacy is diminishing due to drug resistance. Evidence that probiotic strains can act as adjuncts to antibiotic therapy by reducing adverse effects, improving antibiotic function and enhancing mucosal immunity is mounting. It is to our discredit that basic research on microbial ecology has been stalled in Canada for the past 20 years. If supported, research into indigenous and probiotic microbes will form an important part of future research that sheds light on health, disease and a basic understanding of life itself. In some cases, probiotics will be the difference between a good quality of life and a bad one, or perhaps even life over death. Improvements in clinical studies, manufacturing and regulatory standards must coincide with this progress to ensure that physicians and consumers have reliable, proven products for safe and efficacious use.
\end{abstract}

Key Words: Antibacterial; Antibiotics; Biofilms; Immunity; Infection; Probiotics

$\mathrm{T}$ he resurgence of interest in probiotics has been accompanied by many review papers and the use of different definitions. The joint expert panel of the Food and Agriculture Organization of the United Nations and the World Health Organization defines probiotics as "live microorganisms which when administered in adequate amounts confer a health benefit on the host" (1). This definition is preferred because it embraces the historical spirit of the term, and is inclusive of intestinal and other forms of probiotics. The expert panel's report was later accompanied by guidelines that outlined the evidence required for a product to be called a probiotic (2). Although the document was distributed to all member nations, it has not yet been adopted in practical terms in countries such as Canada. Thus, unproven and

\section{Les probiotiques pour prévenir le besoin d'antibiotiques et pour en augmenter l'usage}

Bien que les humains et les microbes soient inséparables, il faut absolument faire des recherches approfondies afin de mieux connaittre et de mieux comprendre la plupart des microbes qui contribuent à nous maintenir en vie et en santé. Nous ne savons pas grand-chose de l'identité, de l'origine, des propriétés métaboliques, des caractéristiques et des mécanismes d'interaction avec l'hôte et les microbes avoisinants des organismes qui influent sur les humains avant la naissance et qui logent dans les diverses niches de l'organisme entre la naissance et le troisième âge. Le recours aux probiotiques (des microorganismes vivants qui, quand ils sont administrés en quantité adéquate, sont bénéfiques à la santé de l'hôte), est réapparu comme moyen de restaurer et de stimuler les microbes bénéfiques de l'organisme. Ce regain d'intérêt envers cet ancien domaine coïncide avec le besoin d'accroître ou de remplacer les antibiotiques, dont les effets secondaires sont importuns et dont l'efficacité est limitée à cause de la résistance aux médicaments. Les données probantes s'accumulent pour démontrer que les souches de probiotiques peuvent agir comme adjuvants à l'antibiothérapie en limitant les effets indésirables, en améliorant la fonction des antibiotiques et en améliorant l'immunité muqueuse. C'est une honte que les recherches fondamentales sur l'écologie microbienne soient en perte de vitesse depuis 20 ans. Si elles sont soutenues, les recherches sur les microbes indigènes et probiotiques formeront une partie importante des futures recherches qui jetteront la lumière sur la santé, la maladie et la vie même. Dans certains cas, les probiotiques feront la différence entre une bonne et une mauvaise qualité de vie ou peut-être entre la mort et la vie. L'amélioration des essais cliniques, la fabrication et les normes de réglementation doivent s'ajouter à ce progrès pour que les médecins et les consommateurs aient des produits fiables et démontrés, pour un usage sécuritaire et efficace.

${ }^{1}$ Department of Microbiology and Immunology, University of Western Ontario; ${ }^{2}$ Canadian Research and Development Centre for Probiotics, The Lawson Health Research Institute, London, Ontario

Correspondence: Dr Gregor Reid, Canadian Research and Development Centre for Probiotics, F2-116, The Lawson Health Research Institute,

268 Grosvenor Street, London, Ontario N6A 4V2. Telephone 519-646-6100 ext 65256, fax 519-646-6031, e-mail gregor@uwo.ca 
The use of products with no basis for ameliorating a condition may lead to the perception that probiotics cannot, for example, prevent urinary tract infections (4), or alleviate irritable bowel syndrome (5) or necrotizing enterocolitis (6), when the use of reliably documented and prepared strains may provide clinical benefits (7-9). Each year, Canadians spend an estimated $\$ 2$ billion per year on alternative therapies, perhaps $\$ 10$ million to $\$ 15$ million of which is spent on 'probiotic' products that are unlikely to provide desirable benefits.

\section{ORIGINS OF PROBIOTICS}

Many reports credit the Russian researcher, Dr Élie Metchnikoff, for influencing the development of probiotics, but the rationale for this approach dates further back to the origins of human life itself. We evolved from single-cell organisms, and throughout evolution, microbes could have terminated our existence had they chosen to do so. People have 10 times more bacteria in their bodies than human cells, and no sterile person has survived on this planet. In other words, we cannot separate microbes from humans. With so many organisms associated with us, including species capable of killing us, why do we live and retain a semblance of health for so long?

Microbiological studies, especially over the past century, have almost exclusively investigated harmful bacteria. Although these studies are necessary, they have been to the exclusion of fundamental studies on the human microbiota, so much so that we do not know the role bacteria play during our fetal development, which ones we inherit, from where, and at what time following birth, and which ones we lack or have in numbers that are insufficient for specific health benefits. Only recently have studies uncovered the role that some species play in intestinal angiogenesis (10), establishment of the immune system (11), processing of fat (12) and potentially even long life (13). Probiotics are simply a means to restore microbial numbers inside the body, because many die or are excreted daily in stool. Selection of probiotic strains, and their application in the most appropriate manner, can only be performed if we understand the fundamental origins of our microbiota and their mechanisms of action. Thus, microbial ecology studies are critical if we are to optimally apply probiotics or modulate the indigenous microbiota in favour of sustained health.

\section{ANTIBIOTIC PROBLEM AREAS}

Collectively, Streptococcus pneumoniae, Staphylococcus aureus, Mycobacterium tuberculosis, vancomycin-resistant enterococci and uropathogenic Klebsiella species that produce extended spectrum beta-lactamases (14-16) cause the majority of infections and pose the biggest problems because of mounting drug resistance. The major problems associated with antibiotics, in addition to the side effects they cause through destruction of the normal microbiota $(17,18)$, are that they are overused along the food chain (19), especially in livestock (20), and in preventing infections (21-25), and are misused by patients (22). It is not surprising to find drugresistant rates for fluoroquinolones, for example, over 30\% (26). In hospitals, the use of antibiotics before and after a range of surgical procedures is now being more limited, particularly because in many cases they are not necessary to protect the host (27). Often in general practice, broad-spectrum agents have been used empirically as a first-line treatment instead of taking steps to determine the causative organism and then use more targeted antibiotics (28). In recent years, with the antibiotic pipeline drying up, physicians have made concerted efforts to more rationally use the current drugs. Nevertheless, new approaches that augment the current arsenal of antibiotics would be welcomed.

\section{EVIDENCE THAT PROBIOTICS CAN AUGMENT ANTIBIOTIC ACTION}

There are perhaps three areas in which probiotics may act as adjuncts to antibiotics. Probiotics may:

- Reduce the risk of antibiotic-induced superinfections in the gut and the vagina;

- Secrete antibacterial substances that lower pathogenic bacterial populations locally and at distant mucosal sites, and disrupt biofilms, making it easier for antibiotics to function; and

- Enhance generalized mucosal immunity, which in turn aids in the eradication of the organisms at the mucosal site.

\section{Diarrhea and superinfections}

The bulk of evidence supporting the idea that probiotics strains are beneficial comes from studies of patients suffering from diarrhea (29-31). The use of probiotics to prevent diarrhea or vaginal infections following antibiotic use makes sense conceptually if the drug adversely affects the intestinal and/or vaginal microbiota, and evidence has been found to support this application (32-34). The currently held belief is that probiotics simply substitute for the microbes that have been destroyed by the antibiotics. This is likely an oversimplification, given that probiotics do not colonize for long periods, and they could act by a number of mechanisms, including indirectly reducing the excess electrolyte release, acting on the physiological process of gut motility, signalling downregulation of toxin release by Clostridium difficile or inhibiting growth of yeast and other opportunistic pathogens. Some probiotic Lactobacillus strains may inhibit or kill intestinal pathogens, including viruses $(35,36)$, and downregulate toxin release in Escherichia coli 0157:H7 (Griffiths MW, personal communication), as well as staphylococcal exotoxin (37). In the case of E coli 0157:H7, antibiotics are not a treatment option because they cause the release of the toxin, and thus, if probiotic organisms functioned in vivo in the same way as suggested by in vitro experiments, this would certainly augment the anti-infective armamentarium. The following five examples are provided to illustrate the evidence for and against the augmentation of antibiotics with the use of probiotics.

Forty-seven Helicobacter pylori subjects were randomly assigned to receive probiotic therapy (Lactobacillus rhamnosus GG, L rhamnosus LC705, Bifidobacterium breve Bb99 and Propionibacterium freudenreichii subspecies shermanii JS) or a placebo during $H$ pylori antibiotic treatment and for three weeks thereafter. No significant differences in individual symptoms were found between the two groups. However, the probiotic group showed fewer treatmentrelated symptoms. The $H$ pylori eradication rate was nonsignificantly higher in the group receiving probiotic therapy than placebo (91\% versus 79\%, $\mathrm{P}=0.42$ ) (38).

In a double-blind, randomized, controlled study (39), 80 infants (six to 36 months of age) were randomly assigned to receive a commercial formula containing $10^{7}$ viable cells of Bifidobacterium lactis and $10^{6}$ viable cells of Streptococcus thermophilus at the initiation of antibiotics for 15 days. There was a significant difference in the incidence of antibiotic-associated diarrhea in children receiving probiotic-supplemented formula (16\%) compared with nonsupplemented formula (31\%). 
In a double-blind, randomized clinical trial of patients with acute intestinal amoebiasis, 27 patients were given metronidazole (750 $\mathrm{mg}$ three times a day) and iodoquinol (630 $\mathrm{mg}$ three times a day) for 10 days (group 1), and 27 patients were also given Saccharomyces boulardii ( $250 \mathrm{mg}$ three times a day) orally (group 2). Diarrhea lasted for $48.0 \pm 18.5 \mathrm{~h}$ in group 1 versus $12.0 \pm 3.7 \mathrm{~h}(\mathrm{P}<0.0001)$ in group 2. Durations of fever and abdominal pain for group 1 were $24.0 \pm 8.8 \mathrm{~h}$ and $24.0 \pm 7.3 \mathrm{~h}$, respectively, and the durations of fever and abdominal pain for group 2 were $12.0 \pm 5.3 \mathrm{~h}$ and $12.0 \pm 3.2 \mathrm{~h}$, respectively $(\mathrm{P}<0.001)$. At week 4, amoebic cysts were detected in five patients (18.5\%) from group 1 , but none from group $2(\mathrm{P}<0.02)(40)$.

In another assessment of $S$ boulardii efficacy, 269 children (six months to 14 years of age) with otitis media and/or respiratory tract infections were enrolled in a double-blind, randomized, placebo-controlled trial in which they received standard antibiotic treatment plus $250 \mathrm{mg}$ of $S$ boulardii or a placebo orally, twice daily, for the duration of the antibiotic treatment. Patients who received $S$ boulardii had a lower prevalence of diarrhea (three or more loose or watery stools per day for at least $48 \mathrm{~h}$, occurring during or up to two weeks after the antibiotic therapy) than those who received placebo (nine of 119 [8\%] versus 29 of 127 [23\%], respectively). $S$ boulardii also reduced the risk of antibioticassociated diarrhea (caused by $\mathrm{C}$ difficile or otherwise unexplained diarrhea) compared with placebo (four of 119 [3.4\%] patients versus 22 of 127 [17.3\%] patients, respectively) (41).

One hundred thirty-eight patients who received antibiotic therapy were randomly assigned to receive either a probiotic containing both Lactobacillus and Bifidobacterium, or placebo for 20 days. The trial probiotic or placebo was taken within $72 \mathrm{~h}$ of administration of antibiotics. On the basis of development of diarrhea, the incidence of samples positive for $\mathrm{C}$ difficile-associated toxins was $2.9 \%$ in the probiotic group compared with $7.25 \%$ in the placebo-control group. When samples from all patients were tested (rather than patients who developed diarrhea), $46 \%$ of probiotic patients were toxin-positive compared with $78 \%$ of the placebo group (42).

The use of probiotics in hospitals in Canada has been limited to some extent to prevent $\mathrm{C}$ difficile infections, and more recently to manage constipation. In Germany, a series of studies showed that the use of Lactobacillus plantarum $299 \mathrm{v}$ with oat fibre could significantly lower infections associated with liver transplants, abdominal surgery and pancreatitis (43-45). Given the morbidity and mortality rates associated with these and other serious conditions requiring hospitalization, there is good reason to consider probiotic foods as part of the overall care of the patient. This must be balanced with safety issues of giving live bacteria to seriously ill patients, but complications caused by the probiotics themselves are rare and in most cases, these are handled effectively with antibiotic treatment (46). Indeed, patients receiving steroids for ulcerative colitis have been shown to benefit from the intake of VSL\#3, a probiotic with an extremely high viable count (more than $10^{11}$ cells) (47).

\section{Antibacterial and biofilm effects}

The secretion of antimicrobial compounds, including organic acids, has been a well documented attribute of probiotic bacteria. Their role in conferring distant side effects, such as in the bladder and the respiratory tract, following oral administration, remains to be determined (48-51), but when in direct contact with pathogens, compounds such as lactic acid, hydrogen peroxide and bacteriocins may have adverse effects on their growth, adhesion and biofilm spread (52-54). To date, of the many bacteriocins discovered in lactic acid bacteria, only nisin has been commercially available, but it is not used in clinical settings. The Lactobacillus strain GR-1 can generate oxidative stress responses that inhibit Candida albicans, prevent its biofilm formation, and depending on the conditions, can actually kill the fungus (55). The ability to stress the outer membrane of $E$ coli has also recently been discovered in our study group, in part due to its lactic acid and hydrogen peroxide secretion (unpublished data). This may lead to detachment of pathogens from surfaces (53) and altered expression of cell membrane proteins involved in the structural stability in E coli (unpublished data).

One net effect of stressing bacteria may be an increased ability of antibiotics to function. In a recent randomized, placebocontrolled study (56) of 106 women treated with metronidazole administered orally for seven days to treat bacterial vaginosis, plus a 30-day course of probiotic Lactobacillus GR-1 and Lactobacillus RC-14, or placebo, the 30-day cure rate was doubled by the administration of the lactobacilli. This augmentation of antibiotic efficacy has been further examined in vitro, and the dose of amoxicillin required to kill uropathogenic $E$ coli was halved with the coinclusion of supernatant from Lactobacillus GR-1 (unpublished data). Similar effects arise from lactic acid use. While this may benefit patients when the lactobacilli are in close proximity to the pathogen, such as in the mouth, intestine and vagina, it is not clear if and how it can augment antibiotic function at distant sites.

\section{Enhancing generalized mucosal immunity}

It is clear from a growing number of investigations that probiotic organisms modulate immunity. This may play a role in eradicating pathogens from local and distant mucosal sites (49,51,58-60). Intriguingly, potentially pathogenic bacteria living in the nose and possibly inducing allergic reactions as well as being a source of other infections (61), can have their cell counts significantly lowered by ingestion of a probiotic drink containing Lactobacillus GG, Bifidobacterium B420, Lactobacillus acidophilus 145 and $S$ thermophilus (62), which implies some sort of immunological interference. It is known that pathogenic Staphylococcus epidermidis has evolved phenol-soluble modulins, which help detach the organisms, and induce inflammation in the switch between aggressive and quiescent modes of infection (63). However, the ability of lactobacilli or other nonpathogenic species to induce a switch in pathogen virulence and/or biofilm formation remains to be uncovered. One possible mechanism is by the use of autoinducer quorum-sensing molecules, shown recently to be produced by probiotic Lactobacillus strains (unpublished data). Coupled with anti-inflammatory mediators, such as the one produced by L rhamnosus GR-1 that suppresses interleukin-12 and tumour necrosis factor-alpha production through inducing secretion of granulocyte colony-stimulating factor (64), quorum sensing may indeed play an important role in preventing or ameliorating inflammation and associated diseases.

\section{CONCLUSION}

Clearly, this exciting field is at a new beginning. If supported, research into indigenous and probiotic microbes will form an important part of future research that sheds light on health, disease and a basic understanding of life itself.

ACKNOWLEDGEMENTS: The author acknowledges the support provided by NSERC and colleagues at the Canadian R\&D Centre for Probiotics. He declares a conflict by owning patents asscoiated with Lactobacillus GR-1 and RC-14 for female urogenital health. 


\section{REFERENCES}

1. Food and Agriculture Organization of the United Nations and World Health Organization. Health and nutritional properties of probiotics in food including powder milk with live lactic acid bacteria, a joint $\mathrm{FAO} / \mathrm{WHO}$ expert consultation. <http://www.who.int/foodsafety/publications/fs_management/en/ probiotics.pdf $>$ (Version current at September 14, 2006).

2. Reid G; Food and Agricultural Organization of the United Nation and the WHO. The importance of guidelines in the development and application of probiotics. Curr Pharm Des 2005;11:11-6.

3. Huff BA. Caveat emptor. "Probiotics" might not be what they seem. Can Fam Physician 2004;50:583-7.

4. Baerheim A, Larsen E, Digranes A. Vaginal application of lactobacilli in the prophylaxis of recurrent lower urinary tract infection in women. Scand J Prim Health Care 1994;12:239-43.

5. Bausserman M, Michail S. The use of Lactobacillus GG in irritable bowel syndrome in children: A double-blind randomized control trial. J Pediatr 2005;147:197-201.

6. Dani C, Biadaioli R, Bertini G, Martelli E, Rubaltelli FF. Probiotics feeding in prevention of urinary tract infection, bacterial sepsis and necrotizing enterocolitis in preterm infants. A prospective double-blind study. Biol Neonate 2002;82:103-8.

7. Reid G, Bruce AW, Taylor M. Instillation of Lactobacillus and stimulation of indigenous organisms to prevent recurrence of urinary tract infections. Microecol Ther 1995;23:32-45.

8. O'Mahony L, McCarthy J, Kelly P, et al. Lactobacillus and Bifidobacterium in irritable bowel syndrome: Symptom responses and relationship to cytokine profiles. Gastroenterology 2005;128:541-51

9. Lin HC, Su BH, Chen AC, et al. Oral probiotics reduce the incidence and severity of necrotizing enterocolitis in very low birth weight infants. Pediatrics 2005;115:1-4.

10. Stappenbeck TS, Hooper LV, Gordon JI. Developmental regulation of intestinal angiogenesis by indigenous microbes via Paneth cells. Proc Natl Acad Sci USA 2002;99:15451-5.

11. Mazmanian SK, Liu CH, Tzianabos AO, Kasper DL. An immunomodulatory molecule of symbiotic bacteria directs maturation of the host immune system. Cell 2005;122:107-18.

12. Backhed F, Ding H, Wang T, et al. The gut microbiota as an environmental factor that regulates fat storage. Proc Natl Acad Sci USA 2004;101:15718-23.

13. Brummel T, Ching A, Seroude L, Simon AF, Benzer S. Drosophila lifespan enhancement by exogenous bacteria. Proc Natl Acad Sci USA 2004;101:12974-9.

14. Pitout JD, Nordmann P, Laupland KB, Poirel L. Emergence of Enterobacteriaceae producing extended-spectrum beta-lactamases (ESBLs) in the community. J Antimicrob Chemother 2005;56:52-9.

15. Senol G, Erbaycu A, Ozsoz A. Incidence of cross resistance between rifampicin and rifabutin in Mycobacterium tuberculosis strains in Izmir, Turkey. J Chemother 2005;17:380-4.

16. Kluytmans-Vandenbergh MF, Kluytmans JA, Voss A Dutch guideline for preventing nosocomial transmission of highly resistant microorganisms (HRMO). Infection 2005;33:309-13.

17. Finegold SM. Anaerobic infections and Clostridium difficile colitis emerging during antibacterial therapy. Scand J Infect Dis Suppl 1986;49:160-4.

18. Reid G, Bruce AW, Cook RL, Llano M. Effect on urogenital flora of antibiotic therapy for urinary tract infection. Scand J Infect Dis 1990;22:43-7.

19. Rizzotti L, Simeoni D, Cocconcelli P, Gazzola S, Dellaglio F, Torriani S. Contribution of enterococci to the spread of antibiotic resistance in the production chain of swine meat commodities. J Food Prot 2005;68:955-65.

20. Anderson AD, Nelson JM, Rossiter S, Angulo FJ. Public health consequences of use of antimicrobial agents in food animals in the United States. Microb Drug Resist 2003;9:373-9.

21. Jones J. Prophylactic antibiotic use in clean neurosurgery: Of potential benefit or harm to the patient? J Wound Care 2005; 14:39-41.

22. Pallasch TJ. Antibiotic prophylaxis: Problems in paradise. Dent Clin North Am 2003;47:665-79.

23. Kardas P, Devine S, Golembesky A, Roberts C. A systematic review and meta-analysis of misuse of antibiotic therapies in the community. Int J Antimicrob Agents 2005;26:106-13.
24. Navas E. Problems associated with potential massive use of antimicrobial agents as prophylaxis or therapy of a bioterrorist attack. Clin Microbiol Infect 2002;8:534-9.

25. Stapleton A, Stamm WE. Prevention of urinary tract infection. Infect Dis Clin North Am 1997;11:719-33.

26. Oteo J, Lazaro E, de Abajo FJ, Baquero F, Campos J; Spanish members of EARSS. Antimicrobial-resistant invasive Escherichia coli, Spain. Emerg Infect Dis 2005;11:546-53.

27. Rapp RP. Emerging bacterial pathogens: A consensus of the scientific data and the risk for development of multiple organ dysfunction syndrome. Surg Infect (Larchmt) 2000;1:187-94; discussion 195-6.

28. Linder JA, Huang ES, Steinman MA, Gonzales R, Stafford RS. Fluoroquinolone prescribing in the United States: 1995 to 2002 Am J Med 2005;118:259-68

29. Guandalini S, Pensabene L, Zikri MA, et al. Lactobacillus GG administered in oral rehydration solution to children with acute diarrhea: A multicenter European trial. J Pediatr Gastroenterol Nutr 2000;30:54-60.

30. Shornikova AV, Casas IA, Isolauri E, Mykkanen H, Vesikari T. Lactobacillus reuteri as a therapeutic agent in acute diarrhea in young children. J Pediatr Gastroenterol Nutr 1997;24:399-404.

31. Kurugol Z, Koturoglu G. Effects of Saccharomyces boulardii in children with acute diarrhoea. Acta Paediatr 2005;94:44-7.

32. Reid G, Sanders ME, Gaskins HR, et al. New scientific paradigms for probiotics and prebiotics. J Clin Gastroenterol 2003;37:105-18.

33. Sanders ME, Guarner F, Mills D, et al. Selected topics in probiotics and prebiotics: Meeting report for the 2004 international scientific association for probiotics and prebiotics. Curr Issues Intest Microbiol 2005;6:55-68.

34. Reid G, Hammond JM, Bruce AW. Effect of lactobacilli oral supplement on the vaginal microflora of antibiotic treated patients: Randomized, placebo-controlled study. Nutraceut Food 2003;8:145-8.

35. Reid G, Charbonneau D, Gonzalez S, Gardiner G, Erb J, Bruce AW. Ability of Lactobacillus GR-1 and RC-14 to stimulate host defences and reduce gut translocation and infectivity of Salmonella typhimurium. Nutraceut Food 2002;7:168-73.

36. Reid G. The extra intestinal effects of probiotics. In: Gibson GR, ed. Interventions for Improving Human Health. London: Wiley and Sons Ltd, 2006:201-211.

37. Laughton JM, Devillard E, Heinrichs DE, Reid G, McCormick JK. Inhibition of expression of a staphylococcal superantigen-like protein by a soluble factor from Lactobacillus reuteri. Microbiology 2006;152:1155-67.

38. Myllyluoma E, Veijola L, Ahlroos T, et al. Probiotic supplementation improves tolerance to Helicobacter pylori eradication therapy - A placebo-controlled, double-blind randomized pilot study. Aliment Pharmacol Ther 2005;21:1263-72.

39. Correa NB, Peret Filho LA, Penna FJ, Lima FM, Nicoli JR. A randomized formula controlled trial of Bifidobacterium lactis and Streptococcus thermophilus for prevention of antibiotic-associated diarrhea in infants. J Clin Gastroenterol 2005;39:385-9.

40. Mansour-Ghanaei F, Dehbashi N, Yazdanparast K, Shafaghi A. Efficacy of Saccharomyces boulardii with antibiotics in acute amoebiasis. World J Gastroenterol 2003;9:1832-3.

41. Kotowska M, Albrecht P, Szajewska H. Saccharomyces boulardii in the prevention of antibiotic-associated diarrhoea in children: A randomized double-blind placebo-controlled trial. Aliment Pharmacol Ther 2005;21:583-90.

42. Plummer S, Weaver MA, Harris JC, Dee P, Hunter J. Clostridium difficile pilot study: Effects of probiotic supplementation on the incidence of $C$ difficile diarrhoea. Int Microbiol 2004;7:59-62.

43. Rayes N, Seehofer D, Theruvath T, et al. Supply of pre- and probiotics reduces bacterial infection rates after liver transplantation - A randomized, double-blind trial. Am J Transplant 2005;5:125-30.

44. Rayes N. John M Kinney International Award for Nutrition and Metabolism. Lactobacilli and fibers - A strong couple against bacterial infections in patients with major abdominal surgery. Nutrition 2004;20:579-80.

45. Olah A, Belagyi T, Issekutz A, Gamal ME, Bengmark S. Randomized clinical trial of specific lactobacillus and fibre 
supplement to early enteral nutrition in patients with acute pancreatitis. Br J Surg 2002;89:1103-7.

46. Senok AC, Ismaeel AY, Botta GA. Probiotics: Facts and myths. Clin Microbiol Infect 2005;11:958-66.

47. Bibiloni R, Fedorak RN, Tannock GW, et al. VSL\#3 probiotic-mixture induces remission in patients with active ulcerative colitis. Am J Gastroenterol 2005;100:1539-46.

48. Ohashi Y, Nakai S, Tsukamoto T, et al. Habitual intake of lactic acid bacteria and risk reduction of bladder cancer. Urol Int 2002;68:273-80.

49. Gill HS, Rutherfurd KJ, Cross ML. Dietary probiotic supplementation enhances natural killer cell activity in the elderly: An investigation of age-related immunological changes. J Clin Immunol 2001;21:264-71.

50. Hatakka K, Savilahti E, Ponka A, et al. Effect of long term consumption of probiotic milk on infections in children attending day care centres: Double blind, randomised trial. BMJ 2001;322:1327.

51. Turchet P, Laurenzano M, Auboiron S, Antoine JM. Effect of fermented milk containing the probiotic Lactobacillus casei DN-114001 on winter infections in free-living elderly subjects: A randomised, controlled pilot study. J Nutr Health Aging 2003;7:75-7.

52. Strus M, Brzychczy-Wloch M, Kochan P, Heczko P. [Hydrogen peroxide produced by Lactobacillus species as a regulatory molecule for vaginal microflora.] Med Dosw Mikrobiol 2004;56:67-77.

53. Reid G, Anukam K, James VI, et al. Oral probiotics for maternal and newborn health. J Clin Gastroenterol 2005;39:353-4

54. Valdez JC, Peral MC, Rachid M, Santana M, Perdigon G Interference of Lactobacillus plantarum with Pseudomonas aeruginosa in vitro and in infected burns: The potential use of probiotics in wound treatment. Clin Microbiol Infect 2005;11:472-9.

55. Reid G, Kim SO, Kohler GA. Selecting, testing and understanding probiotic microorganisms. FEMS Immunol Med Microbiol 2006;46:149-57.
56. Anukam K, Osazuwa E, Ahonkhai I, et al. Augmentation of antimicrobial metronidazole therapy of bacterial vaginosis with ora probiotic Lactobacillus rhamnosus GR-1 and Lactobacillus reuteri RC-14: Randomized, double-blind, placebo controlled trial. Microbes Infect 2006;8:1450-4.

57. Reid G. Colonization of the vagina and urethral mucosa. In: Nataro JP, Cohen PS, Mobley HLT, Weiser JN, eds. Colonization of Mucosal Surfaces. Washington: ASM Press, 2004:431-48.

58. Noverr MC, Huffnagle GB. Does the microbiota regulate immune responses outside the gut? Trends Microbiol 2004;12:562-8.

59. Link-Amster H, Rochat F, Saudan KY, Mignot O, Aeschlimann JM. Modulation of a specific humoral immune response and changes in intestinal flora mediated through fermented milk intake. FEMS Immunol Med Microbiol 1994;10:55-63. (Erratum in 1995;12:83,273).

60. Di Caro S, Tao H, Grillo A, et al. Effects of Lactobacillus GG on genes expression pattern in small bowel mucosa. Dig Liver Dis 2005;37:320-9.

61. Gluck U, Gebbers JO. Local pathogenic bacteria in allergic rhinitis: A novel concept of its pathogenesis. ORL J Otorhinolaryngol Relat Spec 2003;65:202-5.

62. Gluck U, Gebbers JO. Ingested probiotics reduce nasal colonization with pathogenic bacteria (Staphylococcus aureus, Streptococcus pneumoniae, and beta-hemolytic streptococci). Am J Clin Nutr 2003; 77:517-20

63. Yao Y, Sturdevant DE, Otto M. Genomewide analysis of gene expression in Staphylococcus epidermidis biofilms: Insights into the pathophysiology of S epidermidis biofilms and the role of phenol-soluble modulins in formation of biofilms. J Infect Dis 2005;191:289-98.

64 Kim SO, Sheikh HI, Ha SD, Martins A, Reid G. G-CSF-mediated inhibition of JNK is a key mechanism for Lactobacillus rhamnosusinduced suppression of TNF production in macrophages. Cell Microbiol 2006. (In press) 


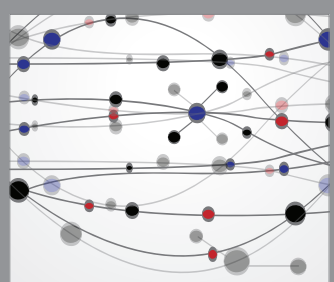

The Scientific World Journal
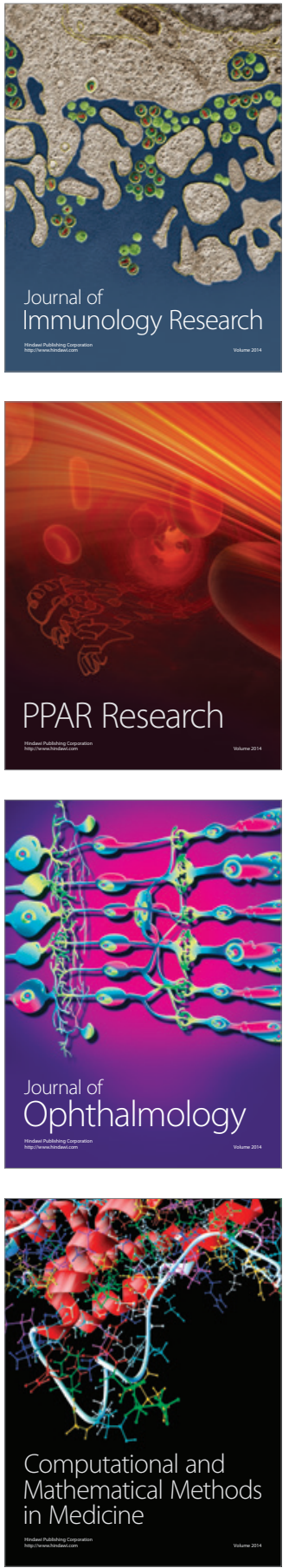

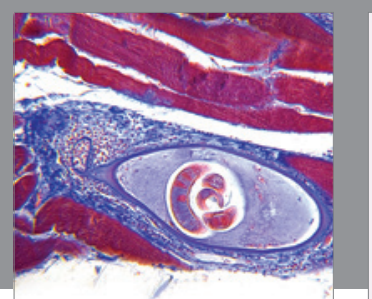

Gastroenterology Research and Practice

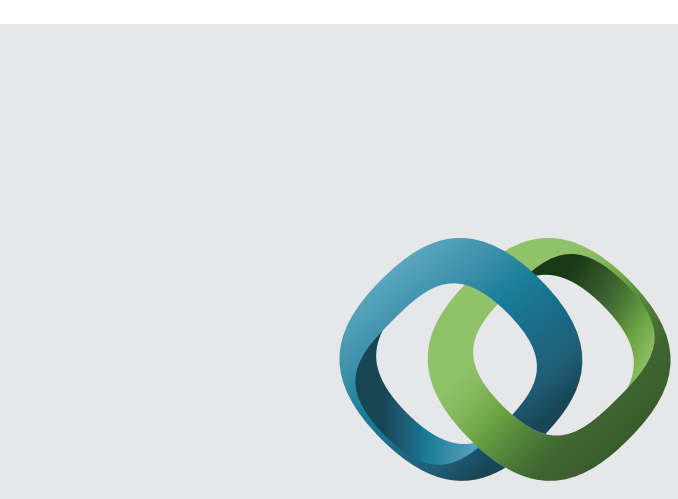

\section{Hindawi}

Submit your manuscripts at

http://www.hindawi.com
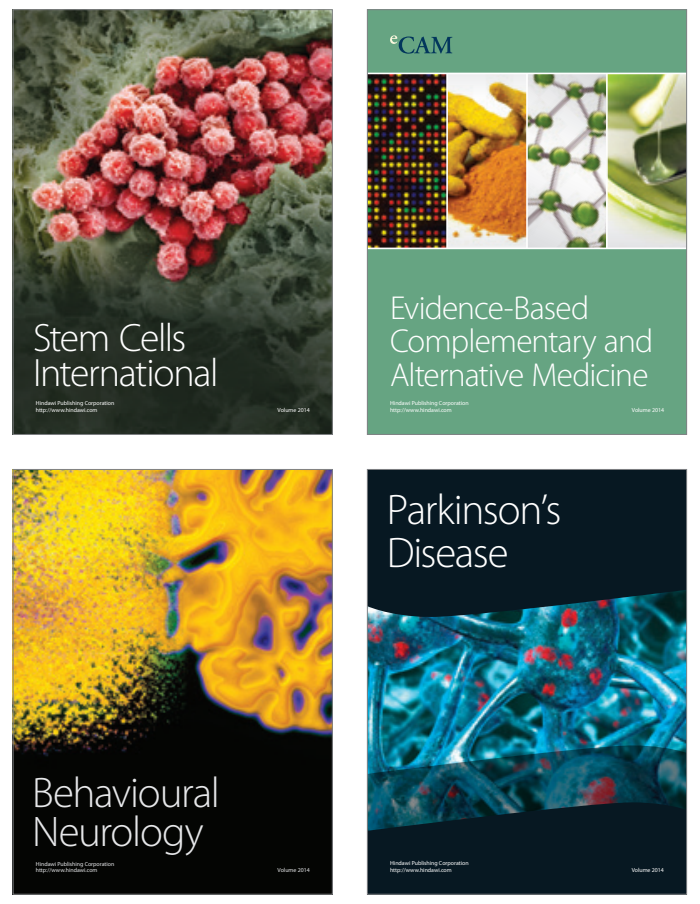
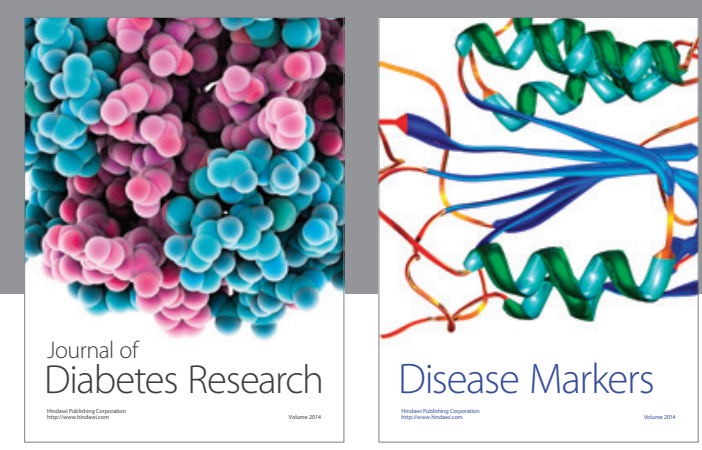

Disease Markers
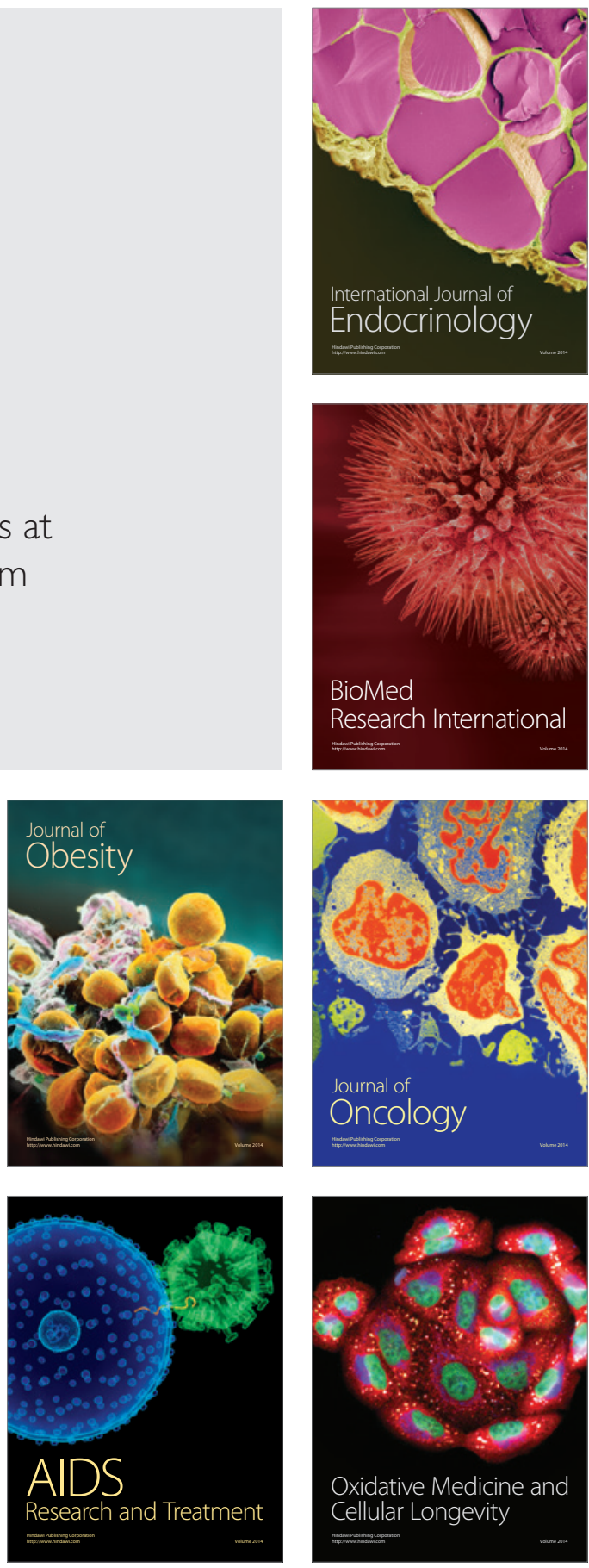